\title{
MEMPERTAHANKAN TUJUAN PERATURAN DAFTAR NEGATIF INVESTASI DALAM MENGENDALIKAN DOMINASI KEPEMILIKAN ASING (STUDI KASUS PADA INDUSTRI TELEKOMUNIKASI)*
}

\author{
Sulistiowati dan Paripurna \\ Fakultas Hukum Universitas Gadjah Mada \\ Jalan Sosio Yustisia 1, Bulaksumur, D.I. Yogyakarta 55281 \\ E-mail: sulistyowati.fhugm@gmail.com dan paripurna@gmail.com
}

\begin{abstract}
Indonesia's Investment Law and Negative Investment List (DNI) are not applicable to capital market transactions. Interpreted literally, this means foreign investors can arbitrarily increase their share participation in a company by engaging capital market transactions. This is not acceptable since the government puts a limit on foreign shares participation in certain business sectors. This normativeempiric study discusses practices in telecommunication industry that deviate from DNI, the consequences, and viable solutions. We found that literal interpretation is inconsistent to the objective of the DNI. We offer alternative approach that is more applicable and suitable to the given objectives.
\end{abstract}

Keywords : negative investment list, foreign ownership restriction, portfolio investment, capital market transaction.

\begin{abstract}
Abstrak
Undang-undang Penanaman Modal dan DNI mengecualikan kegiatan penanaman modal tidak langsung dari ketentuan DNI. Apabila ditafsirkan secara sensu stricto, pengecualian ini menyebabkan investor asing dapat menggunakan transaksi pasar modal untuk meningkatkan kepemilikan saham pengendali secara bebas. Hal ini tidak benar sebab pemerintah telah membatasi partisipasi saham asing pada sektor-sektor usaha tertentu. Penelitian normatif-empiris ini membahas praktik dalam industri telekomunikasi yang menyimpang dari tujuan DNI, akibat yang timbul dari penyimpangan tersebut, serta solusinya. Hasil penelitian menunjukkan bahwa penafsiran secara sensu stricto membawa hasil yang tidak sesuai dengan tujuan DNI. Kami mengusulkan pendekatan alternatif yang lebih sesuai dengan tujuan tersebut.
\end{abstract}

Kata kunci: daftar negatif investasi, pembatasan kepemilikan asing, penanaman modal portofolio, transaksi pasar modal.

\section{Pendahuluan}

Pengaturan investasi asing dilakukan negara sebagai bentuk pengendalian partisipasi asing dalam sektor usaha dalam negeri dan bentuk perlindungan hajat hidup rakyat Indonesia. Indonesia, sebagai negara berkembang, memerlukan penanaman modal asing untuk memenuhi kebutuhan modal pembangunan dan menumbuh-

- Artikel ini merupakan hasil Penelitian Dosen Bagian Hukum Dagang yang didanai oleh Unit Penelitian dan Pengembangan Fakultas Hukum Universitas Gajah Mada tahun anggaran 2012 berdasarkan Surat Kontrak Pelaksanaan Penelitian Nomor: 2980/H.01.H-.FH/N/2011. kan perekonomian nasional.

Penanaman modal asing (selanjutnya disebut PMA) menjadi pilihan untuk memenuhi kebutuhan modal pembangunan. PMA, di Indonesia, diatur dalam peraturan perundangan penanaman modal yang merupakan landasan hukum bagi mengalirnya PMA ke Indonesia. Sejalan dengan perubahan keadaan sosial, politik, dan ekonomi, diperlukan peraturan PMA yang mampu mempercepat perkembangan ekonomi nasional dan mendorong tercapainya sasaran pemba- 
ngunan ekonomi nasional. ${ }^{1}$ Landasan pemikiran ini merupakan alasan pokok lahirnya Undang-undang Nomor 25 Tahun 2007 tentang Penanaman Modal (UU No. 25 Tahun 2007) yang membawa prinsip non-diskriminasi, transparansi, dan kepastian hukum ke dalam rezim pengaturan hukum penanaman modal di Indo-nesia. ${ }^{2}$

Satu hal yang penting untuk dijadikan catatan UU No. 25 Tahun 2007 terkait revitalisasi hukum dasar penanaman modal adalah menyangkut penentuan bidang usaha yang diperbolehkan, serta batasan porsi modal dalam bidang usaha tersebut bagi investor asing. Pasal 12 UU No. 25 Tahun 2007 menyatakan bahwa semua bidang usaha atau jenis usaha terbuka bagi kegiatan penanaman modal, kecuali bidang usaha atau jenis usaha yang dinyatakan tertutup dan terbuka dengan persyaratan. Bidang usaha yang tertutup bagi penanam modal asing adalah produksi senjata, mesiu, alat peledak dan peralatan perang serta bidang usa-ha lain yang secara eksplisit dinyatakan tertutup berdasarkan undang-undang.

Ketentuan lebih lanjut mengenai bidang usaha dan kepemilikan modal telah diatur dalam daftar negatif investasi yang dikodifikasikan dengan suatu peraturan presiden. Daftar negatif yang saat ini sedang berlaku adalah daftar negatif yang termaktub dalam Peraturan Presiden Nomor 36 Tahun 2010 tentang Daftar Bidang Usaha yang Tertutup dan Bidang Usaha yang Terbuka dengan Persyaratan di Bidang Penanaman Modal (Perpres No. 36 Tahun 2010). Perpres No. 36 Tahun 2010 ini sering disebut sebagai daftar negatif investasi (selanjutnya disebut DNI).

Dalam konteks hukum penanaman modal di Indonesia, DNI ditetapkan oleh Badan Koordinasi Penanaman Modal (BKPM) yang berisi bidang usaha yang terbuka sepenuhnya bagi asing,

1 Efrimol, "Kebijakan Pemerintah tentang Pengaturan Mengenai Pertanahan dalam Penanaman Modal dan Investa-si di Indonesia", Inovatif: Jurnal Ilmu Hukum, Vol. 4 No. 5, Tahun 2011, Jambi: Universitas Jambi, hlm. 37-51.

2 Theofransus Litaay, "Peningkatan Investasi di Indonesia Membutuhkan Konsistensi Reformasi Hukum", Kritis, Jurnal Studi Pembangunan Interdisipliner, Vol. XIX No. 3, Tahun 2007, Salatiga: Universitas Kristen Satya Wacana, hlm. 141-155. terbuka dengan persyaratan persentase saham tertentu dikuasai oleh mitra lokal, atau tertutup sama sekali. Sektor yang paling sering dibatasi partisipasi modal asingnya adalah sektor yang dianggap rawan terhadap pengaruh asing, misalnya pertahanan negara atau telekomunikasi. ${ }^{3}$ DNI berfungsi sebagai kran tertutup, setengah terbuka atau terbuka penuh untuk memastikan adanya keseimbangan tertentu yang hendak dipelihara oleh BKPM, yaitu di satu sisi memerhatikan kepentingan swasta nasional terhadap pemerataan ekonomi dan di pihak lain mendukung kepentingan pertumbuhan ekonomi nasional. Contoh kebijakan yang mendukung pertumbuhan ekonomi nasional adalah kebijakan pembatasan usaha bagi pelaku usaha asing, kewajiban membangun kemitraan dengan usaha kecil dan menengah, serta kewajiban memprioritaskan local content.

Penjelasan Pasal 2 UU No. 25 Tahun 2007 dan Pasal 4 Perpres Nomor 36 Tahun 2010 mengecualikan kegiatan penanaman modal tidak langsung atau portofolio dari ketentuan DNI. Peneliti melihat bahwa pengecualian ini menimbulkan pertanyaan: bagaimanakah posisi BKPM terhadap pembelian saham oleh asing yang mengakibatkan persentasi kepemilikan saham asing pada suatu perusahaan menjadi melebihi apa yang ditentukan oleh DNI? Peneliti mengambil beberapa contoh kasus di bidang telekomunikasi: ketika jumlah kepemilikan saham asing sudah sangat tinggi hingga mencapai $95 \%$ di PT AXIS Telekom Indonesia, namun masih ada beberapa perusahaan telekomunikasi yang andil asingnya relatif sedikit, misalnya PT Telekomunikasi Selular (35\%) dan PT Smartfren Telecom Tbk $(1,82 \%)$. Kepemilikan asing yang tinggi ini bermasalah sebab menurut ketentuan Perpres No. 36 Tahun 2010, kepemilikan modal asing dalam penyelenggaraan jaringan tetap dibatasi maksimal $49 \%$, penyelenggaraan jaringan tetap tertutup dibatasi maksimal $65 \%$, serta penyelenggaraan jaringan bergerak baik berupa selu-

3 Marcelo Moscogliato, "Foreign Direct Investment in Corporations: Restrictions in the United States and Brazil on the Grounds of National Defense", Oregon Review of International Law, No. 9, Year 2007, Oregon: University of Oregon School of Law, page 90. 
ler maupun satelit dibatasi maksimal 65\%. Apakah jumlah yang sangat tinggi ini mengindikasikan telah terjadinya penyimpangan dari tujuan DNI?

\section{Permasalahan}

Berdasarkan latar belakang di atas, permasalahan yang dibahas dalam tulisan ini yaitu: pertama, adakah penyimpangan dari tujuan peraturan DNI dalam mengendalikan kepemilikan saham asing; kedua, akibat dari penyimpangan tersebut; dan ketiga, Bagaimana solusi untuk penyimpangan tersebut.

\section{Metode Penelitian}

Penelitian ini merupakan penelitian yuridis empiris, yaitu penelitian yang memfokuskan kajian pada penelitian kepustakaan. Penelitian kepustakaan bersumber dari bahan hukum primer dan bahan hukum sekunder. Bahan hukum primer mencakup ketentuan hukum nasional dan internasional yang berkenaan dengan permasalahan hukum di dalam penelitian ini, yang meliputi UU No. 25 Tahun 2007 dan aturan-aturan lain yang relevan. Bahan hukum sekunder meliputi buku-buku, hasil seminar, makalah, dan artikel yang berkaitan dengan permasalahan yang diajukan dalam penelitian.

Penelitian dilaksanakan di wilayah DKI Jakarta, karena BKPM sebagai lembaga yang mempunyai kewenangan dalam memberikan izin investasi asing berada di DKI Jakarta. Responden penelitian ini adalah pejabat BKPM yang memiliki kewenangan dalam memberikan izin penanaman modal asing. Narasumber dalam penelitian ini adalah praktisi dan akademisi yang mengetahui dan memahami hukum investasi.

Penelitian kepustakaan menggunakan studi literatur, sedangkan data di lapangan dikumpulkan dengan menggunakan teknik wawancara mendalam. Alat pengumpulan data dalam penelitian lapangan adalah pedoman wawancara, sebagai panduan untuk memperoleh data dari responden dan nara sumber.

Data dianalisis dengan mengumpulkan data yang diperoleh dari penelitian lapangan, peraturan-perundang-undangan, buku-buku dan artikel-artikel, yang diolah serta dianalisis dengan menggunakan metode kualitatif. Data yang diperoleh dari penelitian kemudian dipisahkan antara data yang relevan dengan yang tidak relevan. Selanjutnya, data yang relevan dikaitkan dengan judul, latar belakang masalah dan rumusan masalah. Metode kualitatif merupakan tata cara penelitian yang menghasilkan data deskriptif analitis, yaitu keterangan yang disampaikan oleh responden secara tertulis atau lisan dan juga perilaku nyata, diteliti dan dipelajari sebagai sesuatu yang utuh. ${ }^{4}$

\section{Pembahasan \\ Kewenangan Penyusunan dan Penegakan DNI}

Peraturan perundang-undangan pertama yang secara khusus memuat penyusunan daftar bidang usaha yang partisipasi modalnya dibatasi oleh pemerintah adalah Keppres No. 33 Tahun 1981. Menurut hasil penelusuran peneliti di Sistem Informasi Peraturan Perundang-undangan di Sekretaris Kabinet Republik Indonesia, sebenarnya terdapat dua peraturan yang lebih dulu diundangkan sebelum Keppres No. 33 Tahun 1981, yakni Keppres No. 20 tahun 1973 tentang Badan Koordinasi Penanaman Modal dan Keppres No. 53 Tahun 1977 tentang Badan Koordinasi Penanaman Modal. Akan tetapi, peneliti tidak berhasil memperoleh salinan kedua peraturan tersebut dan sejauh yang peneliti berhasil gali dari Sistem Informasi Pidato Kenegaraan dan Dokumen Rencana Pembangunan Lima Tahun di Badan Perencanaan Pembangunan Nasional, tidak pernah ada frasa "daftar skala prioritas" atau frasa sejenisnya yang dilaporkan dalam pidato ataupun laporan-laporan era 1973-1977. Dalam perkembangan selanjutnya, berbagai keputusan presiden telah mengatur kewenangan penyusunan DSP/DNI secara berbeda-beda. Seperti yang telah disinggung sebelumnya dalam Tinjauan Pustaka, pemerintah menggunakan pendekatan daftar negatif (DNI) sejak periode 1989 dan seterusnya. Selama periode 1977 s.d. 1988, pendekatan yang digunakan adalah pendekatan daftar positif atau skala prioritas (DSP). ${ }^{5}$

4 Soerjono Soekanto, 1986, Pengantar Penelitian Hukum, Jakarta: UI Press, hlm. 250.

5 Stephen Magiera, "Indonesia's Investment Negative List: An Evaluation for Selected Services Sectors", Bulletin of 
Peneliti telah melakukan pemetaan regulasi terkait kewenangan penyusunan DSP/DNI dan merangkum pemetaan regulasi tersebut ke dalam matriks berikut ini.

Tabel 1. Kewenangan Penyusunan DSP/DNI $(1973-2012)$

\begin{tabular}{|c|c|c|c|c|c|c|c|}
\hline \multirow[t]{2}{*}{ Tahun } & & \multicolumn{3}{|c|}{$\begin{array}{c}\text { Kewenangan } \\
\text { BKPM terkait } \\
\text { dengan } \\
\text { DSP/DNI }\end{array}$} & \multicolumn{2}{|c|}{$\begin{array}{l}\text { Hubung- } \\
\text { an } \\
\text { BKPM } \\
\text { dengan } \\
\text { lembaga } \\
\text { teknis } \\
\text { lain } \\
\text { dalam } \\
\text { menyu- } \\
\text { sun } \\
\text { DSP/DNI }\end{array}$} & \multirow[t]{2}{*}{$\begin{array}{c}\text { Wadah } \\
\text { DSP/ } \\
\text { DNI }\end{array}$} \\
\hline & & $a$ & $b$ & $c$ & $d$ & $e$ & \\
\hline $\begin{array}{l}\text { Keppres } \\
20 / 1973 \\
\text { tentang } \\
\text { BKPM }\end{array}$ & \multirow{5}{*}{$\begin{array}{l}n \\
n\end{array}$} & $\begin{array}{c}\mathrm{N} / \\
\mathrm{A}\end{array}$ & $\begin{array}{c}\mathrm{N} / \\
\mathrm{A}\end{array}$ & $\begin{array}{c}\mathrm{N} / \\
\mathrm{A}\end{array}$ & $\begin{array}{c}\mathrm{N} / \\
\mathrm{A}\end{array}$ & $\begin{array}{c}\mathrm{N} / \\
\mathrm{A}\end{array}$ & N/A \\
\hline $\begin{array}{l}\text { Keppres } \\
53 / 1977 \\
\text { tentang } \\
\text { BKPM }^{*}\end{array}$ & & $\begin{array}{c}\mathrm{N} / \\
\mathrm{A}\end{array}$ & $\begin{array}{c}\mathrm{N} / \\
\mathrm{A}\end{array}$ & $\begin{array}{c}\mathrm{N} / \\
\mathrm{A}\end{array}$ & $\begin{array}{c}\mathrm{N} / \\
\mathrm{A}\end{array}$ & $\begin{array}{c}\mathrm{N} / \\
\mathrm{A}\end{array}$ & N/A \\
\hline $\begin{array}{l}\text { Keppres } \\
33 / 1981 \\
\text { tentang } \\
\text { BKPM }\end{array}$ & & 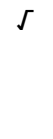 & $\Gamma$ & $\Gamma$ & $\Gamma$ & $x$ & $\begin{array}{l}\text { Tidak } \\
\text { diatur }\end{array}$ \\
\hline $\begin{array}{l}\text { Keppres } \\
78 / 1982 \\
\text { tentang } \\
\text { BKPM }\end{array}$ & & r & $x$ & $\Gamma$ & $x$ & $\Gamma$ & Keppres \\
\hline $\begin{array}{l}\text { Keppres } \\
35 / 1985 \\
\text { tentang } \\
\text { Fungsi BKPM }\end{array}$ & & s & $x$ & $\Gamma$ & 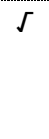 & $x$ & Keppres \\
\hline $\begin{array}{l}\text { Keppres } \\
25 / 1991 \\
\text { tentang } \\
\text { Fungsi BKPM }\end{array}$ & \multirow[b]{3}{*}{$\begin{array}{l}\bar{z} \\
0\end{array}$} & $\bar{J}$ & $x$ & $J$ & $x$ & $\bar{L}$ & Keppres \\
\hline $\begin{array}{l}\text { Keppres } \\
114 / 1998 \\
\text { tentang } \\
\text { Fungsi BKPM }\end{array}$ & & 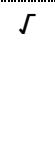 & $x$ & $\Gamma$ & $x$ & $\Gamma$ & Keppres \\
\hline $\begin{array}{l}\text { Keppres } \\
183 / 1998 \\
\text { tentang } \\
\text { BKPM dan } \\
\text { berbagai } \\
\text { peraturan } \\
\text { terkait } \\
\text { fungsi BKPM } \\
\text { s.d. tahun } \\
2007\end{array}$ & & $x$ & $x$ & $\Gamma$ & $x$ & $x$ & - \\
\hline
\end{tabular}

Indonesian Economic Studies, Vol. 47 No. 2, Year 2011, Jakarta: Taylor and Francis Group, page 195-219.

\begin{tabular}{|c|c|c|c|c|c|c|}
\hline \multirow[t]{2}{*}{ Tahun } & \multicolumn{3}{|c|}{$\begin{array}{c}\text { Kewenangan } \\
\text { BKPM terkait } \\
\text { dengan } \\
\text { DSP/DNI }\end{array}$} & \multicolumn{2}{|c|}{$\begin{array}{l}\text { Hubung- } \\
\text { an } \\
\text { BKPM } \\
\text { dengan } \\
\text { lembaga } \\
\text { teknis } \\
\text { lain } \\
\text { dalam } \\
\text { menyu- } \\
\text { sun } \\
\text { DSP/DNI }\end{array}$} & \multirow[t]{2}{*}{$\begin{array}{c}\text { Wadah } \\
\text { DSP/ } \\
\text { DNI }\end{array}$} \\
\hline & $a$ & $b$ & $C$ & $d$ & $e$ & \\
\hline $\begin{array}{l}\text { Perpres } \\
76 / 2007 \\
\text { tentang } \\
\text { Penyusunan } \\
\text { DNI }\end{array}$ & $\begin{array}{l}\mathrm{x} \\
\mathrm{M} \\
\mathrm{e} \\
\mathrm{n} \\
\mathrm{k} \\
\mathrm{o}\end{array}$ & $x$ & $\begin{array}{l}J \\
\mathrm{~B} \\
\mathrm{~K} \\
\mathrm{P} \\
\mathrm{M}\end{array}$ & $x$ & $\begin{array}{l}\mathrm{x} \\
\mathrm{M} \\
\mathrm{e} \\
\mathrm{n} \\
\mathrm{k} \\
\mathrm{o}\end{array}$ & Perpres \\
\hline
\end{tabular}

Keterangan:

a : menyusun;

b : menerbitkan;

c : melaksanakan;

d : bersama-sama;

e : memerhatikan

N/A : Peneliti tidak berhasil memperoleh naskah peraturan yang dikeluarkan pada tahun 1973 dan 1977 ini

Menilik bentuk wadah pengundangan DSP 1977, terlihat bahwa BKPM pernah memiliki peran yang besar sebagai penyusun sekaligus penerbit kebijakan daftar positif investasi Indonesia. Hal ini wajar, mengingat pada periode 1973-1977, BKPM didirikan sebagai pengganti Panitia Teknis Penanaman Modal (PTPM) yang dianggap tidak efisien. Pendirian BPKM membawa janji penyederhanaan prosedur aplikasi penanaman modal dan peningkatan arus penanaman modal asing ke Indonesia, sehingga harapan masyarakat terhadap BKPM kala itu tinggi.

Keppres No. 33 Tahun 1981 kendati tidak mengatur secara tersurat bentuk payung hukum bagi daftar positif investasi, peneliti dapat menyimpulkan dari perkembangan kebijakan penanaman modal Indonesia sebagaimana dilaporkan oleh Presiden Soeharto dalam Pidato Kenegaraannya pada tahun 1985. Pidato Kenegaraan tersebut menyatakan bahwa paling tidak sampai tahun 1981, DSP masih diterbitkan dalam bentuk Keputusan Ketua BKPM. Kesimpulan ini juga didukung oleh Keppres No. 33 Tahun 1981 yang mengatur bahwa BKPM masih mempunyai tugas 
dan fungsi yang cukup luas dalam bidang penanaman modal, yakni: "membantu Presiden dalam menetapkan kebijaksanaan penanaman modal", "melakukan koordinasi perencanaan penanaman modal baik sektoral maupun regional", dan "merumuskan kebijaksanaan penanaman modal".

DSP dan DNI, Mulai tahun 1982 sampai 1998, diterbitkan dalam bentuk keputusan presiden. Sejak tahun 1998, BKPM tidak lagi menjalankan tugas koordinasi perencanaan penanaman modal, tetapi hanya menjalankan tugas koordinasi pelaksanaan kebijakan nasional penanaman modal.

Reformasi di bidang penanaman modal yang dimulai dengan pengundangan UU No. 25 Tahun 2007 ikut mempengaruhi teknis penyusunan DNI. Ketentuan Pasal 17 Perpres No. 76 Tahun 2007 mengatur bahwa penyusunan DNI dikoordinasikan oleh Kementerian Koordinator Bidang Perekonomian (Menko Perekonomian), bukan lagi oleh BKPM. Berdasarkan hasil wawancara peneliti dengan Imam Widijatno di Menko Perekonomian, ditemukan bahwa saat ini DNI merupakan produk bersama BKPM dan Menko Perekonomian. Rapat-rapat penyusunan DNI pada tingkat kajian teknis dilakukan oleh BKPM. Setelah BKPM menyampaikan usulan ketentuan komposisi permodalan dalam DNI, Menko Perekonomian akan mengadakan rapat koordinasi dengan kementerian terkait.

Penjelasan di atas menunjukkan bahwa ada mekanisme double checking; BKPM bertindak sebagai pengkaji teknis yang merumuskan ang-ka-angka persentase partisipasi asing dalam komposisi permodalan suatu bidang usaha dan Menko Perekonomian bertindak sebagai pengkaji kebijakan politis. Menurut Widijatno, apabila usulan DNI telah sampai di meja Menko Perekonomian, maka Menko Perekonomian akan mempertimbangkan kebijakan politik dan kepentingan dunia usaha serta rencana makro pengembangan ekonomi karena posisi Menko Perekonomian nantinya akan berhadapan langsung dengan wakil rakyat di DPR.

Penyusunan DNI, walaupun tidak lagi berada di bawah tugas BKPM, Perpres No. 90 Tahun 2007 memberikan tugas bagi BKPM untuk me- ngoordinasi pelaksanaan kebijakan pelayanan penanaman modal dengan mengikuti norma dan standar yang berlaku di bidang pelayanan penanaman modal. Daftar negatif investasi merupakan daftar yang harus dirujuk oleh penanam modal saat mengajukan aplikasi penanaman modal, sehingga daftar negatif investasi bisa dikategorikan sebagai norma yang berlaku di bidang pelayanan penanaman modal. Selain itu menurut narasumber Riyatno, BPKM masih memiliki tugas untuk mengendalikan pelaksanaan penanaman modal termasuk menegakkan DNI.

\section{Ketentuan Pembatasan Kepemilikan Asing da- lam Hukum Penanaman Modal Indonesia}

Ketentuan pembatasan kepemilikan asing dapat dinilai dari: batas maksimal kepemilikan asing, aturan peralihan, aturan pengecualian DNI dari transaksi pasar modal dan aturan mengenai dampak ekspansi bisnis melalui merger and acquisition, serta rights issue terhadap batasan kepemilikan asing. Berdasarkan empat parameter di atas, DNI 2010 merupakan DNI yang paling rinci mengatur pembatasan kepemilikan asing dibandingkan dengan DNI dan DSP tahuntahun sebelumnya.

DNI 2010 memperjelas dampak ekspansi bisnis seperti penggabungan dan pengambilalihan dengan menentukan bahwa DNI yang berlaku adalah DNI yang sesuai dengan batas kepemilikan yang tercantum dalam surat persetujuan perusahaan penerima penggabungan dan perusahaan pengambilalih. Batasan kepemilikan modal asing dalam hal terjadi peleburan mengikuti ketentuan DNI yang sedang berlaku pada saat terbentuknya perusahaan baru hasil peleburan tersebut.

DNI 2010 juga memperkenankan penambahan modal dilakukan melalui right issue. Penanam modal, apabila dalam negeri tidak berminat berpartisipasi dalam penambahan modal tersebut, penanam modal asing dapat memiliki hak untuk memesan efek terlebih dahulu dengan catatan apabila penambahan modal mengakibatkan kepemilikan modal asing melebihi jumlah yang tercantum dalam surat persetujuan perusahaan, penyesuaian dengan batasan maksimum dalam surat persetujuan harus dilakukan 
dalam waktu dua tahun. Seluruh ketentuan terkait dampak ekspansi bisnis ini baru diperkenalkan dalam DNI 2010.

DNI 2010, dilihat dari substansinya, membawa perbaikan pengaturan dengan cara memberikan kelonggaran bagi pemegang saham asing untuk berinvestasi di Indonesia dengan membuka beberapa bidang usaha baru atau dengan meningkatkan batas minimal kepemilikan asing. Beberapa bidang usaha baru yang dibuka bagi asing yaitu: pertama, Usaha dan operasional industri geotermal (sampai $90 \%$ kepemilikan asing, sebelumnya tidak diatur); kedua, Industri gula (sampai 95\% kepemilikan asing, dengan beberapa syarat, sebelumnya tidak diatur); ketiga, pos (49\%, sebelumnya tertutup bagi asing); keempat, Rumah sakit (meningkat dari $65 \%$ menjadi $67 \%$ dan tidak ada lagi pembatasan wilayah operasional); kelima, Bisnis multi-level marketing (dari 60\% menjadi 95\% kepemilikan asing); keenam, Jasa konstruksi (dari 55\% ke 67\%); ketujuh, Galeri seni dan gedung eksibisi benda seni (dari 50\% menjadi 67\%); dan kedelapan, dalam bidang usaha industri perfilman yang tadinya tertutup sepenuhnya bagi penanaman modal asing menjadi terbuka bagi $49 \%$ modal asing.

DNI 2010 membuka lebih banyak kesempatan bagi penanam modal asing. Berbagai macam perlindungan prosedural seperti grand fathering clause dan aturan-aturan terkait merger and acquisition serta right issue menunjukkan bahwa DNI 2010 terlihat sangat terbuka terhadap masuknya modal asing. Hal ini sesuai dengan pendapat pejabat BKPM yang peneliti mewawancarai, yakni Bapak Riyatno, bahwa setiap pembaruan DNI akan diupayakan untuk membawa lebih banyak kebebasan bagi asing untuk menanamkan modal mereka.

Satu hal yang perlu dipertanyakan terkait perlindungan modal asing dalam DNI 2010 adalah pencantuman ketentuan yang membuat DNI tidak berlaku terhadap transaksi saham yang terjadi di pasar modal. Setelah polemik IndosatQtel pada tahun 2008, pemerintah mencoba untuk meningkatkan kepercayaan dunia investasi melalui penguatan kepastian hukum dengan cara mengatur saham yang dibeli di pasar modal tidak akan ikut diperhitungkan dalam kalkulasi partisipasi asing di suatu perusahaan.

Pengaturan tersebut justru menimbulkan masalah baru sebagai akibat ketiadaan panduan penafsiran yang jelas mengenai makna dari istilah "penanaman modal tidak langsung atau portofolio yang transaksinya dilakukan melalui pasar modal dalam negeri." Lebih dari itu, beberapa pendapat yang dinyatakan oleh pelaku pasar modal, pemerintah, dan akademisi malah bertentangan satu sama lain. Peneliti akan membahas lebih lanjut mengenai masalah perbedaan penafsiran ini di bagian selanjutnya dari penelitian ini.

\section{Kepemilikan Saham di Sektor Telekomunikasi}

Pembatasan partisipasi asing dalam sektor telekomunikasi di Indonesia telah melunak secara signifikan setelah tahun $2000 .{ }^{6}$ Apakah telah terjadi pelanggaran ketentuan DNI dalam mengendalikan kepemilikan saham asing di sektor telekomunikasi? Dalam rangka menjawab pertanyaan tersebut, diperlukan dua jenis data. Pertama, data perubahan ketentuan DNI dari waktu ke waktu. Data ini penting sebab beberapa ketentuan DNI tidak berlaku surut, atau dengan kata lain ketentuan DNI memiliki aturan peralihan (grandfathering). Hal ini berarti peraturan tersebut hanya akan berlaku prospektif ke depan, sehingga kepemilikan asing yang sekarang berlaku tidak lagi tunduk pada aturan DNI baru. Kedua, data jumlah partisipasi saham asing pada beberapa perusahaan telekomunikasi yang terhitung besar di Indonesia. Peneliti akan membandingkan kedua data ini dan menarik kesimpulan apakah terdapat pelanggaran ketentuan DNI.

Tabel 2. Perbandingan DSP/DNI 1977-2010

6 Lebih lanjut, baca: Roy Chun Lee and Christopher Findlay, "Telecommunications Reform in Indonesia: Achievements and Challenges", Bulletin of Indonesian Economic Studies, Vol. 41 No. 3, Year 2005, Jakarta: Taylor and Francis Group, Page 341-365. 


\begin{tabular}{|c|c|c|c|c|}
\hline & $\begin{array}{l}\text { Atur- } \\
\text { an } \\
\text { Pera- } \\
\text { lihan }\end{array}$ & $\begin{array}{c}\text { DNI } \\
\text { Tidak } \\
\text { Berlaku } \\
\text { bagi } \\
\text { Tran- } \\
\text { saksi } \\
\text { Portofo- } \\
\text { lio }\end{array}$ & $\begin{array}{l}\text { Aturan } \\
\text { Terkait } \\
\text { Dampak } \\
\text { Ekspan- } \\
\text { si Usaha }\end{array}$ & $\begin{array}{c}\text { Jumlah } \\
\text { Maksimum } \\
\text { Saham Asing } \\
\text { dalam Perusa- } \\
\text { haan Teleko- } \\
\text { munikasi }\end{array}$ \\
\hline $\begin{array}{l}\text { DNI } \\
2010\end{array}$ & $\mathrm{Ya}$ & $\mathrm{Ya}$ & $\mathrm{Ya}$ & $65 \%$ \\
\hline $\begin{array}{l}\text { DNI } \\
2007\end{array}$ & $\overline{Y a}$ & - & - & $65 \%$ \\
\hline $\begin{array}{l}\text { DNI } \\
2000\end{array}$ & - & $\overline{Y a}$ & - & $\begin{array}{l}49 \% \text { - direvisi } \\
\text { menjadi } 95 \%{ }^{\text {a }}\end{array}$ \\
\hline $\begin{array}{l}\text { DNI } \\
1998\end{array}$ & - & $\mathrm{Ya}$ & - & $95 \%^{\mathrm{a}}$ \\
\hline $\begin{array}{l}\text { DNI } \\
1995\end{array}$ & - & - & - & $95 \%^{\mathrm{a}}$ \\
\hline $\begin{array}{l}\text { DNI } \\
1993\end{array}$ & - & - & - & $\begin{array}{c}80 \%^{\mathrm{b}}- \\
\text { divestasi } \\
\text { menjadi } 49 \%\end{array}$ \\
\hline $\begin{array}{l}\text { DNI } \\
1991\end{array}$ & - & - & - & $?$ \\
\hline $\begin{array}{l}\text { DNI } \\
1989\end{array}$ & - & - & - & $\begin{array}{c}\text { terbuka untuk } \\
\text { asing }\end{array}$ \\
\hline $\begin{array}{l}\text { DSP } \\
1987\end{array}$ & - & - & - & $?$ \\
\hline $\begin{array}{l}\text { DSP } \\
1986\end{array}$ & - & - & - & ? \\
\hline $\begin{array}{l}\text { DSP } \\
1985\end{array}$ & - & - & - & $?$ \\
\hline $\begin{array}{l}\text { DSP } \\
1984\end{array}$ & $\mathrm{Ya}$ & - & - & $?$ \\
\hline $\begin{array}{l}\text { DSP } \\
1983\end{array}$ & $\overline{Y a}$ & - & - & $?$ \\
\hline $\begin{array}{l}\text { DSP } \\
1981\end{array}$ & $?$ & $?$ & $?$ & $?$ \\
\hline $\begin{array}{l}\text { DSP } \\
1978\end{array}$ & $?$ & $?$ & $?$ & $?$ \\
\hline $\begin{array}{l}\text { DSP } \\
1977\end{array}$ & $?$ & $?$ & $?$ & $?$ \\
\hline
\end{tabular}

Keterangan:

? Dokumen tidak berhasil ditemukan

a) Peraturan Pemerintah Nomor 20 Tahun 1994 tentang Pemilikan Saham dalam Perusahaan yang Didirikan dalam Rangka Penanaman Modal Asing mengizinkan perusahaan yang melakukan kegiatan telekomunikasi untuk berbentuk perusahaan patungan dengan modal asing.

b) Peraturan Pemerintah Nomor 50 Tahun 1993 tentang Persyaratan Pemilikan Saham dalam Perusahaan Penanaman Modal Asing menyebutkan bahwa perusahaan yang didirikan dalam rangka penanaman modal asing pada dasarnya berbentuk usaha patungan, di mana pemilikan saham asing pada saat pendirian perusahaan patungan maksimal adalah $80 \%$ dan dalam waktu dua puluh tahun setelah perusahaan berproduksi komersial, andil asing dalam perusahaan tersebut harus dikurangi menjadi 49\%. Perusahaan penanaman modal asing dapat pula didirikan de- ngan 100\% partisipasi asing, tetapi dengan beberapa persyaratan lokasi, jumlah modal minimum, dan kewajiban divestasi.

Tabel 3. Komposisi Saham Operator Telekomunikasi Nasional $(2008,2011,2012)$

\begin{tabular}{|l|c|c|c|c|}
\hline \multirow{2}{*}{ Operator } & \multicolumn{2}{|c|}{ Kepemilikan Saham } & \multirow{2}{*}{ Total } \\
\cline { 2 - 4 } & $\begin{array}{l}\text { Lokal/ } \\
\text { Peme- } \\
\text { rintah }\end{array}$ & Asing & Publik & \\
\hline $\begin{array}{l}\text { PT Bakrie Te- } \\
\text { lecom Tbk } \\
\left(2012^{\mathrm{a}}\right)\end{array}$ & $17.56 \%$ & - & $82.44 \%$ & $100 \%$ \\
\hline $\begin{array}{l}\text { PT Telekomu- } \\
\text { nikasi Selular } \\
\left(2011^{\mathrm{b}}\right)\end{array}$ & $65.0 \%$ & $35.0 \%$ & - & $100 \%$ \\
\hline $\begin{array}{l}\text { PT XL Axiata } \\
\left.\text { Tbk (2012 }{ }^{\mathrm{c}}\right)\end{array}$ & - & $79.9 \%$ & $20.1 \%$ & $100 \%$ \\
\hline $\begin{array}{l}\text { PT Indosat Tbk } \\
\left(2012^{\mathrm{d}}\right)\end{array}$ & $14.29 \%$ & $70.6 \%$ & $15.11 \%$ & $100 \%$ \\
\hline $\begin{array}{l}\text { PT Smartfren } \\
\text { Telecom Tbk } \\
\left(2012^{\mathrm{e}}\right)\end{array}$ & $81.72 \%$ & $1.82 \%$ & $16.46 \%$ & $100 \%$ \\
\hline $\begin{array}{l}\text { PT Telekomu- } \\
\text { nikasi Indone- } \\
\text { sia Tbk (2012 }\end{array}$ & $53.7 \%$ & $15.08 \%$ & $\left.31.22 \%{ }^{\mathrm{f}}\right)$ & $100 \%$ \\
\hline $\begin{array}{l}\text { PT AXIS Tele- } \\
\text { kom Indonesia } \\
\left(2008^{\mathrm{g}}\right)\end{array}$ & $5.0 \%$ & $95.0 \%$ & - & $100 \%$ \\
\hline $\begin{array}{l}\text { PT Hutchison } \\
\text { CP Telecom- } \\
\text { munication } \\
\text { (2008 }\end{array}$ & $37.0 \%$ & $63.0 \%$ & - & $100 \%$ \\
\hline
\end{tabular}

\section{Keterangan:}

a) Laporan Keuangan Interim Konsolidasian PT Bakrie Telecom Tbk dan Entitas Anak (hlm. 57).

b) PT Telekomunikasi Selular 2011 Annual Report (hlm. 16).

c) Laporan Keuangan Konsolidasian Interim PT $\mathrm{XL}$ Axiata Tbk dan Anak Perusahaan (hlm. 44).

d) Laporan Keuangan Interim Konsolidasian PT Indosat Tbk dan Entitas Anak (hlm. 103).

e) Laporan Keuangan Konsolidasian PT Smartfren Telecom Tbk dan Anak Perusahaan (hlm. 92).

f) Laporan Keuangan Konsolidasian PT Telekomunikasi Indonesia Tbk dan Entitas Anak (hlm. 63).

g) CIC Consulting Group, 2008.

h) Sebagaimana dikutip oleh Sumarsono. ${ }^{7}$

Sumarsono, "Studi tentang Kepemilikan Saham dalam Industri Telekomunikasi", Buletin Pos dan Telekomunikasi, Vol. 6, No. 3, Tahun 2008, Jakarta: Kementerian Komunikasi dan Informatika, hlm. 98-125. 
Berdasarkan kedua tabel di atas, perusahaan-perusahaan telekomunikasi berikut ini tidak melanggar ketentuan DNI karena partisipasi saham asing dalam struktur permodalan perusahaan tersebut selalu berada di bawah ambang batas maksimum atau terselamatkan oleh aturan peralihan: PT Bakrie Telecom Tbk (karena andil asing hanya 24,31\%); PT Telekomunikasi Selular (karena andil asing hanya 35\%); PT Smartfren Telecom Tbk (karena andil asing hanya 35,34\%); PT Telekomunikasi Indonesia Tbk (karena andil asing hanya 17,2\%); dan PT Hutchison CP Telecommunication (karena andil asing hanya $63 \%$ ). PT AXIS Telecom Indonesia 95\% dikuasai asing, namun perubahan komposisi ke mayoritas asing ini terjadi pada tahun 2006, di mana pada waktu itu DNI 2007 belum berlaku dan PP No. 20 Tahun 1994 mengizinkan kepemilikan asing sampai dengan 95\% (terselamatkan oleh aturan peralihan).

Bagaimana dengan PT XL Axiata Tbk (XL) dan PT Indosat Tbk (Indosat) yang masing-masing dikuasai oleh $99,9 \%$ dan $70,6 \%$ asing? Penjabaran di bawah menunjukkan bahwa perhitungan andil asing dalam suatu perusahaan telekomunikasi tergantung pada metode akuisisi andil tersebut: melalui pasar modal atau melalui pembelian langsung. Pada akhirnya, perbedaan metode ini berpengaruh pada penerapan DNI.

Tabel 4. Rincian Pemegang Saham XL (\%, 2004-2012)

\begin{tabular}{|c|c|c|c|c|c|c|c|c|c|}
\hline \multirow[b]{2}{*}{$\begin{array}{l}T \\
a \\
h \\
u \\
n\end{array}$} & \multirow[b]{2}{*}{$\begin{array}{l}\text { Lo- } \\
\text { kal }\end{array}$} & \multicolumn{7}{|c|}{ Asing } & \multirow[b]{2}{*}{$\begin{array}{l}\text { Pu } \\
\text { b- } \\
\text { lik }\end{array}$} \\
\hline & & 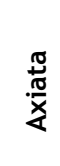 & 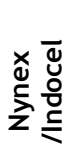 & 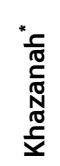 & $\begin{array}{l}\stackrel{0}{ \pm} \\
\stackrel{4}{4}\end{array}$ & 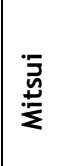 & 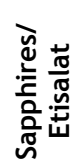 & $\begin{array}{l}\text { Total } \\
\text { Andil } \\
\text { Asing }\end{array}$ & \\
\hline 2004 & 60 & & 23,1 & & 12,7 & 4,2 & 7,58 & 47,58 & 0 \\
\hline 2005 & $\begin{array}{r}15,9 \\
7\end{array}$ & & & $\begin{array}{r}16,8 \\
1\end{array}$ & $\begin{array}{r}10,1 \\
4 \\
\end{array}$ & & & 83,87 & 0,16 \\
\hline 2006 & \begin{tabular}{|r|}
15,9 \\
7
\end{tabular} & & $\begin{array}{r}59,6 \\
3\end{array}$ & $\begin{array}{r}16,8 \\
1\end{array}$ & 7,38 & & & 83,82 & 0,21 \\
\hline 2007 & & & $\begin{array}{r}66,9 \\
9 \\
\end{array}$ & $\begin{array}{r}16,8 \\
1 \\
\end{array}$ & & & 15,97 & 99,77 & 0,23 \\
\hline 2008 & & & 83,8 & & & & 15,97 & 99,77 & 0,23 \\
\hline 2009 & & & 86,5 & & & & 13,3 & 99,8 & 0,2 \\
\hline 2010 & & 66,7 & & & & & 13,3 & 80 & 20 \\
\hline 2011 & & 66,6 & & 13,3 & & & & 79,9 & 20,1 \\
\hline 2012 & & $\begin{array}{r}66,6 \\
1\end{array}$ & & & & & 13,29 & 79,9 & 20,1 \\
\hline
\end{tabular}

Keterangan:
*) Saham Khazanah seluruhnya diperoleh melalui proses IPO XL pada tahun 2005.

Pada tanggal 16 September 2005, XL memperoleh surat pernyataan efektif dari Bapepam untuk melakukan Penawaran Umum Perdana Saham (IPO) sebesar 20\% jumlah saham XL, dari $20 \%$ saham yang dilepas ke publik melalui transaksi pasar modal, $16,8 \%$ saham dibeli oleh Khazanah Bhd dan 3,2\% saham dibeli Indocel, sebuah perusahaan investasi Malaysia. Kepemilikan saham asing di XL pada tahun 2007 adalah sekitar 79,77\% pembelian langsung dan $20 \%$ dibeli melalui IPO.

Tabel 5. Rincian Pemegang Saham Indosat (\%, 2005-2012)

\begin{tabular}{|c|c|c|c|c|c|c|c|c|c|}
\hline \multirow[b]{2}{*}{$\begin{array}{l}\text { Ta- } \\
\text { hun }\end{array}$} & \multirow[b]{2}{*}{ 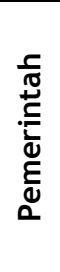 } & \multicolumn{7}{|c|}{ Asing } & \multirow[b]{2}{*}{$\begin{array}{c}\text { Pub- } \\
\text { lik }\end{array}$} \\
\hline & & 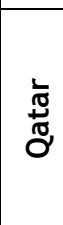 & 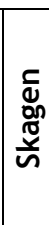 & 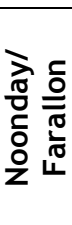 & $\begin{array}{l}\frac{5}{\sigma} \\
\frac{E}{0} \\
\mathcal{O}\end{array}$ & 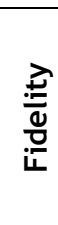 & $\underset{\text { on }}{\text { in }}$ & $\begin{array}{c}\text { To- } \\
\text { tal } \\
\text { An- } \\
\text { dil } \\
\text { A- } \\
\text { sing }\end{array}$ & \\
\hline 2005 & 14,5 & $\begin{array}{r}40,5 \\
4\end{array}$ & & & & & & 40,54 & 44,96 \\
\hline 2006 & $\begin{array}{r}14,2 \\
9\end{array}$ & $\begin{array}{r}39,9 \\
6\end{array}$ & & & & & 0,85 & 40,81 & 44,9 \\
\hline 2007 & $\begin{array}{r}14,2 \\
9\end{array}$ & $\begin{array}{r}39,9 \\
6\end{array}$ & & & & & 6,69 & 46,65 & 39,06 \\
\hline 2008 & $\begin{array}{r}14,2 \\
9\end{array}$ & $\begin{array}{r}40,8 \\
1\end{array}$ & $\begin{array}{l}6 \\
44\end{array}$ & 7,95 & 8,64 & $\begin{array}{r}10,0 \\
5\end{array}$ & & 73,89 & 11,82 \\
\hline 2009 & $\begin{array}{r}14,2 \\
9\end{array}$ & 65 & & & & & & 65 & 20,71 \\
\hline 2010 & $\begin{array}{r}14,2 \\
9\end{array}$ & 65 & $\begin{array}{l}5, \\
11\end{array}$ & & & & & 70,11 & 15,6 \\
\hline 2011 & $\begin{array}{r}14,2 \\
9\end{array}$ & 65 & $\begin{array}{l}5, \\
62\end{array}$ & & & & & 70,62 & 15,09 \\
\hline 2012 & $\begin{array}{r}14,2 \\
9\end{array}$ & 65 & $\begin{array}{r}5, \\
6\end{array}$ & & & & & 70,6 & 15,11 \\
\hline
\end{tabular}

Kasus Indosat-Qtel juga menyajikan keadaan yang kurang lebih sama. Data dalam laporan keuangan menunjukkan bahwa selain dimiliki oleh Qtel 40,81\%, sebagian porsi saham Indosat dimiliki oleh Fidelity, Goldman Sachs, Noonday/Farallon, dan Skagen. Namun, perusahaan-perusahaan asing tersebut memperoleh andil di Indosat melalui transaksi pasar modal. Pada tahun 2012, 65\% saham dimiliki Qtel melalui transaksi privat, dan $5,6 \%$ saham dimiliki Skagen melalui transaksi pasar modal.

\section{Pembelian Saham Langsung dan Pembelian Sa- ham Portofolio}

Pembahasan mengenai keberlakuan DNI terhadap pembelian saham langsung dan pembelian saham portofolio sangat relevan dalam 
konteks pembahasan penyimpangan ketentuan DNI. Perbedaan interpretasi 'pembelian saham portofolio' menyebabkan dunia hukum dan bisnis Indonesia terbagi ke dalam dua kutub pendapat: mereka yang berpendapat bahwa DNI berlaku terhadap pembelian saham portofolio apabila pembelian tersebut mengakibatkan perubahan kendali perusahaan ${ }^{8}$ dan mereka yang berpegang teguh pada tafsiran harfiah bahwa selama pembelian saham terjadi dalam konteks pasar modal atau bursa efek, maka pembelian tersebut tidak tunduk pada ketentuan DNI. ${ }^{9}$

Menurut Velentina dan Hartaty, DNI tidak berlaku terhadap penanaman modal tidak langsung melalui pasar modal dikarenakan dua alasan: pertama, bahwa Perpres No. 77 Tahun 2007 dan Perpres No. 111 Tahun 2007 sebagai baju hukum DNI 2007 merujuk kepada UU No. 25 Tahun 2007 tentang Penanaman Modal. Salah seorang anggota tim perumus RUU Penanaman Modal pada dasarnya membenarkan bahwa dalam rapat-rapat pembahasan RUU Penanaman Modal tampak bahwa para pembuat undang-undang memahami pengertian penanaman modal tidak langsung sebagai penanaman modal di pasar modal. ${ }^{10}$ Mengingat Penjelasan Pasal 2 UU No. 25 Tahun 2007 menegaskan bahwa undang-undang tersebut hanya berlaku bagi penanaman modal langsung, DNI 2007 sebagai aturan pelaksana UU No. 25 Tahun 2007 harus mengikuti ruang lingkup yang telah ditetapkan dalam undang-undang induknya. Kedua, praktik yang selama ini berjalan tidak pernah menetapkan batasan modal asing terhadap perusahaan publik dan tidak ada pembedaan antara pemilik saham asing dan pemilik saham lokal di pasar modal. Pembelian saham melalui pasar modal yang mengakibatkan suatu perusahaan asing memiliki andil lebih tinggi dari yang diperkenankan DNI

8 Lihat juga Trijoyo Ariwibowo, 2009, "Implementasi Daftar Negatif Investasi terhadap Perusahaan Publik: Studi pada PT Indosat Tbk - QTel", Skripsi, Jakarta: Fakultas Hukum Universitas Indonesia.

9 Misalnya, pendapat Rouli Anita Velentina and Lidia Hayaty, "Keberlakuan Daftar Negatif Investasi (Kasus: Investasi Qatar Telecom (Qtel) di Indonesia)", Jurnal Hukum Internasional, Vol. 6 No. 3, Year 2009, Depok: Lembaga Pengkajian Hukum Internasional, page 375-409.

10 ibid, hlm. 340-389. mengakibatkan pembelian saham tersebut tidak tunduk pada ketentuan DNI.

Erman Rajagukguk juga memiliki pendapat yang sama. Menurut beliau, Pemerintah Indonesia secara konsisten telah menerapkan perbedaan antara penanaman modal langsung dan penanaman modal tidak langsung (portofolio), dan telah memberikan pengecualian bagi penanam modal asing yang melakukan penanaman modal tidak langsung untuk dapat memasuki bidang usaha yang terbuka bagi penanaman modal dalam negeri serta tidak tunduk pada ketentuan mengenai pembatasan bidang usaha yang terbuka bagi penanaman modal asing. ${ }^{11}$ Dengan demikian, menurut pendapat tersebut, DNI secara mutlak tidak dapat diberlakukan terhadap saham yang dipegang oleh publik. Dengan kata lain, pandangan tersebut sedikit-banyak menunjukkan pola pikir pandangan positivistik, sebagaimana nampak dari argumen ketidakberlakuan DNI terhadap penanaman modal portofolio dengan alasan DNI yang merupakan aturan pelaksana UU No. 25 Tahun 2007 tidak boleh "mengkhianati" pola pikir pembuat UU No. 25 Tahun 2007 yang secara eksplisit mengecualikan penanaman modal portofolio dari luang lingkup undang-undang $a$ quo.

Menurut peneliti, semangat dan suasana kebatinan penyusunan DNI belum diperhatikan oleh para penulis terdahulu. Seperti yang telah disinggung sebelumnya, DNI disusun dengan tujuan agar ada pembatasan jumlah modal asing yang dapat masuk ke dalam sektor-sektor tertentu agar kendali modal asing dapat dijaga dan tidak berdampak destruktif terhadap ekonomi masyarakat Indonesia. Dominasi asing berpotensi berdampak sangat buruk sebab dominasi asing mengurangi kendali masyarakat atas sumber daya dan kesejahteraan ekonomi masyarakat. Peneliti juga menyadari bahwa modal asing diperlukan untuk merangsang pertumbuhan ekonomi di sektor-sektor yang masih terlalu mahal atau terlalu sulit untuk diusahakan oleh masyarakat Indonesia. Dalam hal ini, diperlukan suatu

\footnotetext{
11 Erman Rajagukguk, 20 November 2012, "Hukum Investasi dan Pasar Modal", http://www.ermanhukum.com/Kuliah/Hukum\%20Investasi\%20Kuliah\%202.pdf. Diakses 10 Februari 2013.
} 
keseimbangan dalam pengaturan dominasi asing di perusahaan penanaman modal. Pasal 12 UU No. 25 Tahun 2007 memberi batasan kriteria bidang usaha yang terbuka dan tertutup bagi modal asing, yakni kriteria kesehatan, moral, kebudayaan, lingkungan hidup, pertahanan dan keamanan nasional, dan kepentingan nasional lainnya.

Menanggapi argumentasi para penulis terdahulu sebagaimana telah dijelaskan di atas, peneliti berpendapat bahwa segala hal yang diperkenankan oleh hukum tidak serta-merta benar secara hakiki, apalagi jika perkenan yang diberikan oleh hukum tersebut ternyata berdasar pada tafsiran hukum yang masih bisa ditantang dengan tafsiran lain.

Pertama, Definisi "transaksi portofolio" itu sendiri masih menjadi perdebatan. Sebagaimana dicantumkan dalam DNI 2010, ketentuan DNI “tidak berlaku bagi penanaman modal tidak langsung atau portofolio yang transaksinya dilakukan melalui pasar modal dalam negeri". Penjelasan makna terminologi "penanaman modal tidak langsung" atau "portofolio" tidak disediakan dalam DNI 2010. Hal inilah yang menjadi penyebab awal timbulnya silang pendapat terkait keberlakuan DNI terhadap penanaman modal portofolio.

Menurut definisi IMF dan OECD, penanaman modal langsung atau direct investment adalah penanaman modal yang bertujuan memperoleh manfaat yang berkelanjutan oleh seorang penduduk suatu negara (penanam modal) dalam suatu perusahaan yang merupakan entitas hukum dalam negara lain (perusahaan penanaman modal asing), sehingga harus ada hubungan jangka panjang antara penanam modal dengan perusahaan di mana ia menanamkan modalnya. Penanam modal, selain itu, harus memiliki pengaruh atau kendali yang signifikan atas manajemen perusahaan penanaman modal. Penanaman modal langsung dapat dilakukan dengan membeli langsung saham perusahaan atau mendirikan perusahaan baru. Penanaman modal asing terjadi ketika warga negara atau perusahaan asing memiliki aset suatu entitas di negara lain untuk jangka waktu yang cukup panjang dengan tujuan mengendalikan atau mengelola en- titas tersebut. Penanaman modal tidak hanya melibatkan pemindahan sumber daya secara nyata, tetapi dapat juga melibatkan pergeseran kendali atas suatu perusahaan.

Menurut Bapepam-LK sebagaimana dikutip oleh Velentina \& Hayaty, penanaman modal dalam bentuk portofolio adalah penanaman modal yang dilakukan melalui pembelian obligasi, surat kertas perbendaharaan negara, emisi saham yang dikeluarkan perusahaan, serta deposito. ${ }^{12}$ Dana investasi yang dikeluarkan oleh investor tidak secara langsung digunakan untuk kegiatan bisnis, namun dipakai untuk membeli saham dan surat berharga lainnya melalui bursa saham.

Berangkat dari penjelasan di atas, peneliti kemudian menganalisis keadaan riil di pasar modal saat ini. Transaksi saham di pasar modal tidak hanya berupa transaksi portofolio investasi semata, melainkan juga berupa transaksi saham pengendali, di mana transaksi saham di pasar modal menyebabkan berubahnya persentase pemegang saham pengendali. Perubahan persentase pemegang saham pengendali tersebut mengakibatkan dapat dikatakannya transaksi saham di pasar modal sebagai transaksi penanaman modal secara langsung.

Salah satu sifat penanaman modal langsung adalah penanam modal memiliki pengaruh atau kendali yang signifikan atas manajemen perusahaan penanaman modal. Peneliti berpendapat bahwa dalam hal pemegang saham kendali ikut bertransaksi di pasar modal, maka ketentuan DNI harus diberlakukan kepada si pemegang saham kendali.

Kedua, Argumentasi yang menyatakan bahwa DNI harus mengadopsi pendirian UU No. 25 Tahun 2007 yang mendikotomikan penanaman modal langsung dan penanaman modal tidak langsung karena baju hukum DNI merupakan peraturan presiden yang merujuk kepada UU No. 25 Tahun 2007, tidak dapat diterima sepenuhnya, karena menurut hemat peneliti, peraturan presiden sebagai baju hukum DNI harus ditelaah terlebih dahulu apakah benar-benar ha-

12 Rouli Anita Velentina and Lidia Hayaty, op.cit., hlm. 381. 
nya "melayani" UU No. 25 Tahun 2007. Konsideran Perpres No. 36 Tahun 2010, misalnya, merujuk kepada berbagai peraturan yang terkait dengan usaha mikro, kecil dan menengah. Hal ini membuktikan bahwa Perpres No. 36 Tahun 2010 tidak hanya berperan mengejawantahkan ketentuan di bidang penanaman modal, tetapi juga ketentuan di bidang ekonomi kecil. Peneliti menafsirkan hal ini sebagai bukti bahwa DNI merupakan instrumen hukum yang berfungsi melayani mandat beberapa peraturan sekaligus, sehingga tidak adil rasanya apabila lantas DNI diklaim sebagai pelaksana UU No. 25 Tahun 2007 saja.

Ketiga, Argumen bahwa past practices telah secara konsisten memperlakukan transaksi pasar modal sebagai transaksi penanaman modal tidak langsung, peneliti tidak menemukan contoh kasus yang berhubungan dengan polemik transaksi saham pengendali. Beberapa kasus yang dikutip adalah perkara portofolio investasi biasa di PT Astra International Tbk; PT Excelcomindo Pratama Tbk; PT Indosiar Karya Media Tbk; PT Indosat Tbk; dan PT Bumi Resources Tbk. ${ }^{13}$ Menurut peneliti, contoh past practices yang seperti ini tidak dapat dijadikan sebagai model karena cakupannya yang kurang luas. Contoh past practices mengenai penguasaan saham pengendali melalui pasar modal seharusnya tersedia, sehingga dampak dari kebijakan yang tidak memberlakukan DNI terhadap semua transaksi pasar modal dapat dipelajari secara lebih menyeluruh, dengan demikian, sebenarnya belum ada legal test maupun preseden yang dapat membantu penafsiran ketentuan Pasal 4 Perpres No. 36 Tahun 2010.

\section{Tujuan DNI dan Akibat yang Timbul dari Pene- rapan Sensu Stricto DNI}

DNI disusun untuk menjamin bahwa sektor-sektor usaha di Indonesia dapat diakses oleh masyarakat dengan kesempatan yang sama, oleh karena itu, BKPM dan Menko Perekonomian menyusun angka-angka partisipasi asing maksimum yang diperkenankan dalam komposisi permodalan suatu sektor usaha. Sebagai contoh, angka partisipasi asing maksimum dalam suatu sektor adalah 65\%. Tentu angka ini dicapai dengan pertimbangan bahwa ada kebutuhan untuk membatasi asing dalam sektor tersebut. Apabila partisipasi asing dalam sektor tersebut mencapai $90 \%$, tentu kondisi tersebut akan kontraproduktif dengan kebutuhan dan kepentingan nasional. Partisipasi domestik dan publik menjadi terdesak dan kesempatan untuk mengakses sektor tersebut menjadi sangat terbatas.

Perlu ditekankan bahwa yang peneliti maksud dengan "partisipasi domestik dan publik" mencakup pula partisipasi investor portofolio. Menurut peneliti, aturan DNI tetap tidak dapat diberlakukan terhadap transaksi yang berlangsung di pasar modal sebab transaksi pasar modal memberikan jaminan akses yang sama kepada para investor, sehingga jiwa dan suasana kebatinan pembentukan DNI sebagaimana yang telah dijabarkan sebelumnya tetap terpenuhi.

Pasar modal bertujuan menunjang pelaksanaan pembangunan nasional dalam rangka meningkatkan pemerataan, pertumbuhan dan stabilitas ekonomi nasional ke arah peningkatan kesejahteraan rakyat. Kegiatan ekonomi yang berlangsung di pasar, sesuai dengan prinsip yang berlaku di pasar pada umumnya, harus diserahkan pada mekanisme pasar atau invisible hand. Pemerintah tidak diharapkan untuk turut campur dalam mekanisme pasar. Tujuan dibentuknya pasar modal adalah untuk mengumpulkan pemilik dana dan mempertemukan mereka dengan pencari dana atau modal. Pasar modal berperan menyerap sebesar-besarnya dana yang ada.

Hambatan yang berpotensi menghalangi tujuan tersebut harus diusahakan untuk dihilangkan. Pasar modal mempunyai peran strategis sebagai salah satu sumber pembiayaan bagi dunia usaha, termasuk usaha menengah dan kecil untuk pembangunan usahanya, dan sebagai wahana investasi bagi masyarakat, termasuk pemodal kecil dan menengah. Penjabaran ini menunjukkan bahwa transaksi yang berlangsung di pasar modal pada hakikatnya juga menjunjung tinggi kesetaraan akses.

13 ibid, hlm. 399-401. 
Peneliti mengakui bahwa pemodal asing diperkenankan untuk turut serta bertransaksi di pasar modal di Indonesia, akan tetapi mengingat bahwa tujuan pasar modal adalah untuk menggalang kapital, maka tidak logis apabila investasi asing dibatasi di pasar modal sebab hal tersebut akan mengurangi esensi dibentuknya pasar modal. Tidak dapat disangkal, bahwa pemodal asing juga merupakan pihak yang akan menginjeksikan dana ke pasar modal Indonesia, bahkan bisa jadi berjumlah lebih besar daripada pemodal dalam negeri. Investasi portofolio telah terbukti secara empiris berpengaruh positif terhadap pertumbuhan ekonomi bersama-sama dengan penanaman modal langsung (foreign direct investment). ${ }^{14}$

Hal yang perlu diperhatikan di sini bukanlah apakah asing harus dibatasi atau tidak, melainkan apakah partisipasi asing menghalangi akses masyarakat Indonesia ke dalam bursa. Menurut pendapat peneliti, transaksi saham yang dilakukan oleh investor asing non-pemegang saham pengendali merupakan transaksi yang wajar, sebab transaksi tersebut tidak akan menguntungkan investor asing dalam jumlah yang berlebihan. Sebaliknya, transaksi yang dilakukan oleh investor asing pemegang saham pengendali akan menyebabkan investor tersebut memiliki saham dengan jumlah yang sangat besar, bahkan bisa jadi melebihi ketentuan maksimum yang ada dalam DNI.

Sebagai kesimpulan, peneliti menganggap bahwa transaksi saham yang dilakukan oleh pemegang saham non-pengendali tetap dapat dibenarkan untuk tidak tunduk kepada ketentuan DNI, karena transaksi tersebut dilaksanakan berdasarkan asas kesetaraan akses di mana investor memiliki akses yang setara untuk mengakuisisi saham suatu perusahaan PMA. Transaksi yang dilakukan oleh pemegang saham pengendali, misalnya Qtel dalam kasus Indosat, tidak dapat dibenarkan sebab transaksi tersebut berpotensi

14 Houssem Rachdi and Hichem Saidi, "The Impact of Foreign Direct Investment and Portfolio Investment on Economic Growth in Developing and Developed Economies", Interdisciplinary Journal of Research in Business, Vol. 1, No. 6, Year 2011, Bellville: Institute of Interdisci-plinary Business Research, page 10-17. menganulir tujuan pembentukan DNI, yakni bahwa sektor-sektor usaha di Indonesia bisa diakses oleh masyarakat dengan kesempatan yang sama. Qtel, bilamana mengakuisisi saham Indosat baik secara independen maupun melalui afiliasi atau subsidiary, maka Qtel telah melakukan penyelundupan hukum (fraus legis) dalam bentuk berusaha memiliki saham di atas ketentuan DNI. Akibat yang terjadi cukup fatal, yakni peluang masyarakat menjadi sempit dan pada akhirnya bahkan bisa ada potensi praktik usaha yang monopolistik.

Penanaman modal langsung secara sensu stricto diartikan sebagai penanaman modal di luar pasar modal. Menurut hemat peneliti, pengertian secara sempit seperti itu akan menimbulkan implikasi yang tidak sesuai dengan suasana kebatinan dan tujuan disusunnya DNI, yakni untuk menjamin bahwa fungsi kendali dalam suatu perusahaan yang dimiliki asing tidak merugikan Indonesia, sebab pengertian tersebut tidak mengakomodasi praktik pembelian saham di pasar modal oleh pemegang saham pengendali. Tujuan penyusunan DNI adalah untuk menciptakan mekanisme penyeimbang kepentingan menerima injeksi dana asing dengan kepentingan ekonomi akar rumput. Peneliti berpendapat bahwa dikotomi yang terlalu ketat yang memisahkan keberlakuan DNI terhadap transaksi pasar modal dengan keberlakuan DNI terhadap penanaman modal langsung akan menikam sendiri tujuan DNI sebagai penyeimbang kepentingan, sebagai contoh, LG, Ltd adalah perusahaan asing pemegang saham pengendali yang memiliki andil sebesar $30 \%$ pada suatu PT PMA yang menurut DNI hanya diperkenankan memiliki 35\% andil asing, apabila kemudian LG, Ltd membeli 6\% saham PT PMA yang dijual ke publik melalui pasar modal (entah secara terang-terangan ataupun menggunakan perusahaan afiliasi atau anak perusahaan), apakah LG, Ltd dapat dikenakan ketentuan DNI karena pembelian saham PT PMA di pasar modal tersebut dihitung sebagai penanaman modal langsung? Menurut beberapa sarjana, jawaban atas pertanyaan tersebut adalah tidak. DNI tidak berlaku sebab batas kepemilikan asing tidak ikut memperhitungkan saham yang dibeli melalui pasar modal. Peneliti 
beranggapan bahwa jawaban atas pertanyaan tersebut adalah ya dengan dasar pemikiran bahwa tidak peduli venue transaksi sahamnya, apabila suatu transaksi saham melibatkan keikutsertaan pemegang saham pengendali dan apabila transaksi tersebut berujung pada meningkatnya jumlah saham pengendali melebihi ketentuan DNI, maka transaksi tersebut dikategorikan sebagai penanaman modal langsung dan dengan demikian tunduk pada ketentuan DNI.

Penulis berpendapat bahwa pemberlakuan DNI bagi suatu transaksi saham jangan didasarkan atas faktor bagaimana transaksi saham dilakukan (apakah secara langsung atau melalui pasar modal), melainkan didasarkan atas pertimbangan apakah transaksi saham tersebut melibatkan transaksi saham pengendali. Transaksi saham di pasar modal, apabila tidak mengakibatkan perubahan porsi pemegang saham pengendali, maka transaksi saham di pasar modal tersebut dapat disebut sebagai transaksi saham portofolio. Transaksi saham portofolio tidak melibatkan saham pengendali sehingga DNI sudah sewajarnya tidak diberlakukan, sebaliknya apabila transaksi saham di pasar modal mengakibatkan perubahan porsi pemegang saham pengendali, maka transaksi saham tersebut peneliti klasifikasikan sebaagai penanaman modal lang-sung, karena melibatkan kegiatan perubahan kendali perusahaan.

\section{Solusi dari Penyimpangan Tujuan DNI dan Ken- dalanya}

Kepastian hukum sangat berpengaruh terhadap niat investor menanamkan modal ke negara berkembang, baik secara langsung maupun tidak langsung. Faktor ekonomi tidak selalu menjadi faktor utama pendorong aliran investtasi. Faktor-faktor lain seperti faktor politik dan kepastian hukum (rule of law) ${ }^{15}$ atau faktor infrastruktur dan keuangan negara ${ }^{16}$ terbukti pen-

15 Joseph L. Staats and Glen Biglaiser, "The Effects of Judicial Strength and Rule of Law on Portfolio Investment in the Developing World", Social Science Quarterly, Vol. 92 No. 3, 2011, Texas: Southwestern Sociological Association, page 609-630.

16 Tidiane Kinda, 2010, "On the Drivers of FDI and Portfolio Investment: A Simultaneous Equations Approach", Inter- ting bagi investor dalam mengambil keputusan investasi. Menurut Kinda, faktor infrastruktur memengaruhi penanaman modal langsung, dan faktor perkembangan finansial memengaruhi penanaman modal tidak langsung. Faktor-faktor ini dinamakan "push and pull factors."

Peneliti menawarkan dua solusi yang dapat ditempuh untuk merestorasi penyimpangan tujuan DNI yang terjadi akibat ketentuan Pasal 4 Perpres No. 36 Tahun 2010. Solusi pertama adalah dengan menyatakan bahwa ketentuan DNI berlaku terhadap transaksi pasar modal yang melibatkan pemegang saham pengendali. Pemegang saham pengendali, dengan demikian tidak dapat membeli saham tambahan dari transaksi pasar modal dalam jumlah tertentu yang mengakibatkan agregat saham yang dibelinya di pasar modal ditambah agregat saham yang dibeli secara langsung melebihi ketentuan DNI. Ketentuan ini juga berlaku bagi perusahaan afiliasi si pemegang saham pengendali dan anak-anak perusahaannya. Dasar pemberlakuan larangan ini adalah pemikiran bahwa pembelian saham tambahan melalui bursa efek oleh pemegang saham pengendali merupakan indikasi adanya upaya fraus legis atau penyelundupan hukum untuk mengakuisisi saham di atas jumlah yang diperkenankan DNI. Solusi peneliti tersebut dapat dimodifikasi, misalnya dengan menetapkan bahwa pemegang saham pengendali dapat menambah sahamnya via pasar modal tanpa tambahan voting rights, sehingga akuisisi saham suatu perusahaan di pasar modal oleh pemegang saham pengendali hanya akan memberikan keuntungan ekonomi bagi si pemegang saham, namun tidak membuatnya memonopoli kendali perusahaan yang bersangkutan.

Solusi kedua adalah dengan menetapkan plafon jumlah saham publik yang boleh dibeli oleh investor portofolio asing di pasar modal dalam negeri Indonesia. Sebenarnya kebijakan ini pernah diberlakukan di Indonesia satu dasawarsa yang lalu. Kementerian Keuangan di bawah kepemimpinan J.B. Sumarlin pernah menerapkan pembatasan partisipasi saham asing di pasar

national Economic Journal, Vol. 26 No. 1, Wisconsin: Korea International Economic Association, page 1-22. 
modal maksimal sebesar 49\% (vide: Keputusan Menteri Keuangan No. 1055/KMK.013/1989).

Kedua solusi di atas tentu memiliki kendala dalam pelaksanaannya. Peneliti menemukan bahwa apabila BKPM hendak menerapkan pembatasan partisipasi asing di pasar modal sebagaimana disarankan oleh peneliti di subbab sebelumnya, BKPM dapat terkendala dengan masalah habituasi. Menurut pengamatan peneliti, masyarakat bisnis telah terhabituasi atau telah terbiasa untuk menganggap bahwa transaksi di pasar modal tidak tunduk pada ketentuan DNI. Hal ini terlihat dari pengungkapan risiko perusahaan beberapa emiten dalam halaman pertama prospektus mereka dewasa ini. Contoh pengungkapan risiko tersebut adalah sebagaimana disebutkan dalam Prospektus PT Solusi Tunas Pratama Tbk pada 2011:

"Sesuai dengan Pasal 2 Perpres No. 36 Tahun 2010, usaha Perseroan di bidang penyediaan dan pengelolaan (penyewaan dan pengoperasian) menara telekomunikasi hanya dapat dimiliki dengan modal dalam negeri $100 \%$. Akan tetapi, sesuai dengan Pasal 4 Perpres No. 36 Tahun 2010 pembatasan kepemilikan saham asing tersebut tidak berlaku bagi penanaman modal tidak langsung atau portofolio yang transaksinya dilakukan melalui pasar modal dalam negeri."

Contoh lain, Prospektus PT Pelayaran Nelly Dwi Putri Tbk pada 2012:

"Bahwa terhadap bidang usaha Perseroan di bidang pelayaran ini terdapat pembatasan kepemikikan saham asing sebesar maksimal 49\%. Akan tetapi sesuai dengan Pasal 4 Perpres No. 36 Tahun 2010, pembatasan kepemilikan saham asing tersebut tidak berlaku bagi penanaman modal tidak langsung atau portofolio yang transaksinya dilakukan melalui pasar modal dalam negeri."

Kedua prospektus di atas merupakan bukti bahwa investor dalam negeri dan investor asing telah terbiasa menganggap bahwa Pasal 4 Perpres No. 36 Tahun 2010 menyebabkan seluruh transaksi pasar modal tidak terpengaruh oleh ketentuan DNI. BKPM, terhadap habituasi ini, mungkin akan menghadapi kendala berupa respon negatif investor asing terhadap usulan pemberlakuan DNI bagi transaksi saham di pasar modal yang melibatkan pemegang saham kendali. Berikut ini adalah kutipan posisi Indosat dalam Laporan Tahunan 2010 terhadap pemberlakuan DNI kepa-da transaksi saham di pasar modal.

\begin{abstract}
"Sebagai perseroan terbuka, kami percaya bahwa Daftar Negatif Investasi tidak berlaku bagi kami. Apabila pihak regulator yang berwenang hendak memberlakukan Daftar Negatif Investasi terhadap Perusahaan, terlepas dari status Perusahaan sebagai perseroan terbuka, pemegang saham pengendali dan/ atau pemegang saham asing lain kami dapat diminta untuk mengurangi kepemilikan sahamnya pada Perusahaan, hal mana dapat mempengaruhi penurunan harga perdagangan saham Perusahaan. Hal ini dapat membawa pengaruh negatif yang material terhadap usaha, kondisi keuangan, hasil usaha dan prospek kami [...] Sebagai tambahan, apabila pihak regulator yang berwenang menetapkan bahwa, kepemilikan asing di Perusahaan masih melebihi batasan yang ditetapkan dalam Daftar Negatif Investasi, regulator yang berwenang mungkin melarang kami untuk mengikuti tender atau untuk memperoleh izin lain atau spektrum tambahan. Apabila hal ini terjadi, usaha, peluang, kondisi keuangan dan hasil usaha kami menjadi terpengaruh."
\end{abstract}

Berdasarkan kutipan di atas, terlihat bahwa kekhawatiran pengusaha lebih disebabkan karena ketakutan mereka terhadap kemungkinan reaksi negatif dari pasar karena terjadi instabilitas dan kejadian yang tidak terduga (unexpected circumstances). Pengusaha, selain itu, khawatir harga saham mereka akan turun apabila kepemilikan saham mereka dipaksa untuk dikurangi. Peneliti berpendapat bahwa kendala dalam penerapan kebijakan pemberlakuan DNI terhadap pemegang saham kendali ini akan sangat mungkin dipandang investor asing sebagai kemunduran ke rezim ketertutupan pasar modal. Sebagai perbandingan, Korea Selatan sen- 
diri telah menghapus pembatasan investasi asing sejak tahun $2000 .^{17}$

Reaksi negatif yang telah dijabarkan di atas memang sangat berpengaruh terhadap kondisi pasar modal yang sensitif. Akan tetapi menurut peneliti, kekhawatiran terhadap penurunan harga saham ini tidak dapat dijadikan landasan bagi pemerintah untuk mengizinkan pemegang saham kendali dalam membeli saham tambahan melalui metode transaksi di pasar modal dan secara semena-mena mengabaikan kepentingan nasional untuk mewujudkan tujuan utama DNI, yakni keseimbangan akses antara penanam modal dalam negeri dengan penanam modal asing. Semua perubahan regulasi akan selalu dihadapi oleh stakeholders terkait. Pemerintah tidak perlu khawatir terhadap reaksi negatif tersebut. Kasus Indosat-Qtel sudah cukup menjadi peringatan: pengaturan hukum positif yang mengizinkan tidak tunduknya saham asing yang dibeli oleh pemegang saham kendali me-lalui pasar modal kepada DNI telah mengakibatkan investor asing memperoleh hampir $80 \%$ saham di Indosat setahun setelah keluarnya kebijakan pemerintah yang menyatakan bahwa maksimal kepemilikan asing bagi Indosat adalah $65 \%$.

Penulis berpendapat bahwa reaksi negatif yang dikhawatirkan pengusaha dapat ditekan melalui sosialisasi dan keterbukaan informasi kepada publik, apabila sedari awal sudah disadari bahwa transaksi di pasar modal dapat tunduk kepada ketentuan DNI jika transaksi tersebut melibatkan pemegang saham kendali, maka acceptance masyarakat akan lebih tinggi. Pemerintah perlu melakukan komunikasi dan dialog yang baik dengan para investor untuk meyakinkan bahwa kebijakan pemberlakuan DNI terhadap transaksi portofolio pemegang saham kendali akan dapat diterapkan dengan mulus. Selain itu, diperlukan sosialisasi dan sinkronisasi pera-turan kepasarmodalan dengan peraturan

17 GonJaik-Sik Gong and Choong-Hwan Kim, "The Characteristics of Foreign Portfolio Investment", Journal of the Korea Academia - Industrial Cooperation Society, Vol. 12 No. 1, Year 2011, Cheonan: The Korea Academia-Industrial Cooperation Society, page 216-221. pena-naman modal agar perbedaan penafsiran tidak terjadi.

\section{Penutup \\ Simpulan}

Peneliti berkesimpulan bahwa terdapat penyimpangan tujuan peraturan DNI dalam mengendalikan kepemilikan saham asing. Munculnya penafsiran hukum bahwa pembelian saham di pasar modal, oleh siapa pun dan berapa pun jumlahnya, tidak tunduk pada ketentuan DNI, disebabkan oleh tidak jelasnya makna "penanaman modal tidak langsung" dan "portofolio" dalam DNI 1998, 2000, dan 2010. Sebagai akibatnya, banyak pihak yang merasa bahwa selama dana diinjeksikan melalui mekanisme pasar modal, maka dana tersebut tidak tunduk pada ketentuan DNI. Padahal, ada kemungkinan di mana dana yang diinvestasikan melalui transaksi pasar modal oleh pemegang saham kendali ternyata mengakibatkan jumlah andil si pemegang saham kendali tersebut melebihi ketentuan DNI. Hal ini tentu akan menyebabkan suatu pemegang saham kendali memiliki jumlah total partisipasi saham yang jauh lebih tinggi dari partisipasi yang diperkenankan dalam DNI.

Peneliti menemukan, bahwa walaupun interpretasi sensu stricto terhadap Pasal 4 Perpres No. 36 Tahun 2010 dimungkinkan, interpretasi tersebut tidak lantas menjadi secara hakiki tepat atau benar. Menurut hemat peneliti, interpretasi seperti itu berpotensi mengakibatkan tidak tercapainya tujuan DNI yaitu menyeimbangkan kepentingan nasional untuk menerima injeksi modal asing dengan kepentingan masyarakat. Gaya berpikir demikian juga menunjukkan kecacatan dalam UU No. 25 Tahun 2007 dan aturan pelaksananya yang memungkinkan pihak asing untuk menguasai saham sebesar-besarnya melalui pasar modal.

Penyimpangan qua substantiva tujuan DNI ini menimbulkan potensi DNI kehilangan peran pentingnya sebagai garda terdepan penegakan rezim hukum penanaman modal. Timbulnya potensi tersebut dikarenakan penanam modal asing dapat dengan mudah mem-bypass ketentuan restriksi penanaman modal melalui transaksi 
saham di pasar modal untuk menambah ekuitas mereka.

\section{Saran}

Peneliti mengusulkan agar pemerintah menyatakan secara tegas bahwa partisipasi saham melalui pasar modal yang dilakukan oleh pemegang saham kendali wajib tunduk pada ketentuan DNI atau dengan mengatur bahwa saham yang dibeli oleh pemegang saham pengendali di pasar modal tidak memiliki voting rights. Solusi lain adalah dengan menetapkan plafon sa-ham perusahaan publik yang dapat dibeli oleh perusahaan asing di pasar modal Indonesia dan memperkenalkan sosialisasi dan sinkronisasi per-aturan kepasarmodalan agar perbedaan penaf-siran tidak terjadi.

\section{Daftar Pustaka}

Ariwibowo, Trijoyo. 2009. Implementasi Daftar Negatif Investasi terhadap Perusahaan Publik: Studi pada PT Indosat Tbk-QTel. Skripsi. Jakarta: Fakultas Hukum Universitas Indonesia;

Efrimol. "Kebijakan Pemerintah tentang Pengaturan Mengenai Pertanahan dalam Penanaman Modal dan Investasi di Indonesia". Inovatif: Jurnal Ilmu Hukum. Vol. 4 No. 5. Tahun 2011. Jambi: Universitas Jambi;

Gong, GonJaik-Sik and Choong-Hwan Kim. "The Characte-ristics of Foreign Portfolio Investment". Journal of the Korea AcademiaIndustrial Cooperation Society. Vol. 12 No. 1. Year 2011. Cheonan: The Korea Academia-Industrial Cooperation Society;

Kinda, Tidiane. 2010. "On the Drivers of FDI and Portfolio Investment: A Simultaneous Equations Approach". International Economic Journal. Vol. 26 No. 1. Wisconsin: Korea International Economic Association;

Lee, Roy Chun and Christopher Findlay. "Telecommunications Reform in Indonesia: Achievements and Challenges". Bulletin of Indonesian Economic Studies. Vol. 41 No. 3. Year 2005. Jakarta: Taylor and Francis Group;

Litaay, Theofransus. "Peningkatan Investasi di Indonesia Membutuhkan Konsistensi Reformasi Hukum". Kritis. Jurnal Studi Pembangunan Interdisipliner. Vol. XIX No. 3.
Tahun 2007. Salatiga: Universitas Kristen Satya Wacana;

Magiera, Stephen. "Indonesia's Investment Negative List: An Evaluation for Selected Services Sectors". Bulletin of Indonesian Economic Studies. Vol. 47 No. 2. Year 2011. Jakarta: Taylor and Francis Group;

Moscogliato, Marcelo. "Foreign Direct Investment in Corporations: Restrictions in the United States and Brazil on the Grounds of Natio-nal Defense". Oregon Review of Interna-tional Law. No. 9. Year 2007. 0regon: University of Oregon School of Law;

Rachdi, Houssem and Hichem Saidi. "The Impact of Foreign Direct Investment and Portfolio Investment on Economic Growth in Developing and Developed Economies". Interdisciplinary Journal of Research in Business. Vol. 1. No. 6. Year 2011. Bellville: Institute of Interdisciplinary Business Research;

Rajagukguk, Erman. 20 November 2012. "Hukum Investasi dan Pasar Modal". http://www. ermanhukum.com/Kuliah/Hukum\%20Inves tasi\%20Kuliah\%202.pdf. Diakses tanggal 10 Februari 2013.

Soekanto, Soerjono. 1986. Pengantar Penelitian Hukum. Jakarta: UI Press;

Staats, Joseph L and Glen Biglaiser. "The Effects of Judicial Strength and Rule of Law on Portfolio Investment in the Developing World". Social Science Quarterly. Vol. 92 No. 3. 2011. Texas: Southwestern Sociological Association;

Sumarsono. "Studi tentang Kepemilikan Saham dalam Industri Telekomunikasi". Buletin Pos dan Telekomunikasi. Vol. 6. No. 3. Tahun 2008. Jakarta: Kementerian Komunikasi dan Informatika;

Velentina, Rouli Anita and Lidia Hayaty. "Keberlakuan Daftar Negatif Investasi (Kasus: Investasi Qatar Telecom (Qtel) di Indonesia)". Jurnal Hukum Internasional. Vol. 6 No. 3. Year 2009. Depok: Lembaga Pengkajian Hukum Internasional. 